\title{
FACTORS AFFECTING ACCOUNTING LEARNING ACHIEVEMENT
}

\author{
By: \\ Brilia Afnizar Litasari \\ Accounting Education Department Yogyakarta State University \\ brilia.afnizar@gmail.com \\ Adeng Pustikaningsih \\ Lecturer of Accounting Education Department Yogyakarta State University
}

\begin{abstract}
This study aimed to know the influence of (1) Locus of Control (2) Student Perceptions of Teaching Methods (3) The Use of Learning Resources, and (4) Locus of Control, Student Perceptions of Teaching Methods, and The Use of Learning Resources simultaneously toward Accounting Learning Achievement Students Class of X, XI, XII Accounting SMK Muhammadiyah 2 Moyudan Academic Year 2017/2018. Data collection technique used in this research was questionnaire and documentation. Population of this research was students of class X, XI, and XII Accounting SMK Muhammadiyah 2 Moyudan. The research showed that there is a (1) positive and significant influence of Locus of Control toward Accounting Learning Achievement 2) positive and significant influence of Student Perceptions of Teaching Methods toward Accounting Learning Achievement (3) positive and significant influence of The Use of Learning Resources toward Accounting Learning Achievement (4) positive and significant influence of Locus of Control, Student Perceptions of Teaching Methods, and The Use of Learning Resources simultaneously toward Accounting Learning Achievement.
\end{abstract}

Keywords: Accounting Learning Achievement, Locus of Control, Student Perceptions of Teaching Methods, The Use of Learning Resources

\section{INTRODUCTION}

Education is one of some tools to reach the national goals and support the progress of a nation. Education becomes the key and provision for human to survive and able to compete in global era. Human intelligence, skills, and personality are also enhanced through education. Hasbullah (2012: 4), stated that education is a planned effort to create a good learning atmosphere and learning process, so the students actively develop their potential to have spiritual strength, self-control, personality, intelligence, noble character, and also the skill needed by him and society, nation and state.

Effective and efficient learning process is one of keys to success of education, therefore the learning process must be created well in a learning environment. Learning process is an activity that builds interactive and educative communication between teachers and students through certain strategies, approaches, principles, and methods in order to deliver the subject matter to the students to achieve the learning objectives. That is, the quality of education is closely related to the learning process traversed by students. School, as a formal educational institution formed by the government for its residence to gain knowledge, is required to measure the success of the learning process through student achievement.

Student achievement is the level of ability that has been achieved after following the learning process in time (Sudjana, 2005: 22). Student achievement can be measured by mastering learning objectives through Minimum Criteria of Mastery Learning which is determined in accordance with applicable regulations. The 
determination of Minimum Criteria of Mastery Learning depends on the policies set by each school. Student who succeed in achieving Minimum Criteria of Mastery Learning, can be considered to have fulfilled minimal mastery. Arikunto (2006: 142), stated two forms of test there are subjective test and objective test. Subjective test is type of progress learning test that requires a discussion of answers, than objective test is a test in which examination can be done objectively.

SMK Muhammadiyah 2 Moyudan is one of vocational high schools in Sleman Regency, which based on the interview with the accounting teachers stated that students accounting learning achievement from class $\mathrm{X}$ until class XII is still low. As evidenced by $36 \%$ of students of class $\mathrm{X}$ in the subjects of Basic Banking still not reached the Minimum Criteria of Mastery Learning. So do the class XI of Accounting, less than $50 \%$ of students reached the Minimum Criteria of Mastery Learning in managing accounts receivables card subject. Less than 50\% students of Class XII Accounting reached the Minimum Criteria of Mastery Learning in arranging financial statements subject.

Ahmadi and Supriyono (2004: 138) stated that learning achievement is the results of interaction from various factors that influence both internal factors and external factors. Slameto (2013: 54), stated that factors that influence learning are internal and external factors. Internal factors including physical factors, psychological factors, and exhaustion factors. External factors including family factors, school factors, and community factors.

One of internal factor which may affect learning achievement is Locus of Control. According to Robbins \& Judge (2009: 138), Locus of Control is the level at which individuals are convinced that they are determinants of their own destiny. Locus of Control is divided into two types namely internal Locus of Control and external Locus of Control. Gufron \& Rini (2014:
67), stated that people who have an internal control center believe that what happens to them is because of themselves. Nodoushan (2012: 123) stated that Locus of Control refers to whether individuals relate their success or failure to their own behavior.

Moskowitz and Orgel in Walgito (2010: 100) stated that perception is an integrated process within the individual against the stimulus it receives. Learning method is about how to deliver materials in the learning process so students can get the optimal result (Sugihartono, 2013: 81). Then, Student Perceptions of Teaching Methods is students' understanding of how teachers deliver the learning material during the learning activities. There are various learning methods available Teachers are expected to choose the right method in the learning process.

According to Edgar Dale in Sitepu (2014: 18) also revealed that the learning resources are everything that is used to support and facilitate the learning process. Learning resources including environment, people, procedures, tools, concepts, theory, technology, media, and problem solving procedures (Darmawan, 2014: 3). Association of Educational Communication and Technology (AECT) stated six types of learning resources there are message, person, material, tool, technique, and environment. Teachers have responsibility of helping learners to make learning easier, smoother, and more focused in the use of learning resources (Karwono \& Mularsih, 2017: 158).

The introduction of factors that affect learning achievement is very important in order to assist students to achieve the best learning achievement (Ahmadi \& Supriyono, 2004: 138). Based on preliminary study, students of class X, XI, and XII Accounting SMK Muhammadiyah 2 Moyudan indicates that the majority of students have external Locus of Control, this is because students believe that subjects related to accounting is a difficult thing to learn. Students become less motivated to 
learn more diligently. Another factor that influences learning achievement is the teaching methods of the teachers. Teachers teaching method is a way that teachers apply so that students can absorb the material optimally. This is very necessary for the educator because the success of accounting learning process is determined by how the teacher teaches.

Based on the observation of the implementation of learning in the class that has been done by researchers at SMK Muhammadiyah 2 Moyudan, the teachers have done the learning stages well, but the teacher always use the lecture method for any situation. This method has not been effective because students are always rowdy during teaching and learning activities. The lack of learning support facilities such as LCD and projector has become an obstacle for teachers. Student participation still depends on the question and answer method applied. Then the results of observations about the use learning resources showed that students of class X, XI, and XII Accounting less use of existing learning resources such as Student Worksheets (LKS), as well as books in the library.

The use of learning resources is still low. Based on borrow list book in the library of SMK Muhammadiyah 2 Moyudan $84,8 \%$ students of class X Accounting only borrow less than 5 book in a semester, so does class XI Accounting with number of $72,7 \%$, and class of XII Accounting with the number of $87,5 \%$.

Based on the preliminary observation of the research indicate that the factors influenced accounting learning achievement were internal and external factor. The reseacher is interested to do research with the title "The Influence of Locus of Control, Student Perceptions of Teaching Methods, and The Use of Learning Resources on Accounting Learning Achievement Students Class of X, XI, XII Accounting SMK Muhammadiyah 2 Moyudan Academic Year 2017/2018".

\section{RESEARCH METHODS \\ Research Design}

This research is an ex-post facto research that belongs to causal research. This study aims to examine the influence of independent variable Locus of Control (X1), Student Perceptions of Teaching Methods (X2), and The Use Learning Resources (X3), to the dependent variable that is Accounting Learning Achievement (Y). The approach used in this study is a quantitative approach, because the research data used in the form of numbers and using statistics to analyze (Sugiyono, 2014: 7).

\section{Place and Time of the Research}

This research was conducted in SMK Muhammadiyah 2 Moyudan located in Ngentak, Sumberagung, Moyudan, Sleman in class X, XI, and XII Accounting Academic Year 2017/2018., from January to February 2018.

\section{Population and Sample}

The population in this study are the students of class X, XI, and XII Accounting SMK Muhammadiyah 2 Moyudan consisting of 4 classes with a total of 81 students.

\section{Data Collection Technique}

The data collection techniques used in this study was questionnaire. According to Arikunto (2013: 194) questionnaires are a number of written statements used to obtain information from respondents in the sense of reports about his personality, or things he knows. Questionnaires in this study are used to obtain data on Locus of Control, Student Perceptions of Teaching Methods, and The Use of Learning Resources. Then, documentation in this research is used to collect the achievement of the student.

\section{Data, Instrument, and Analysis} Technique

Researcher do the trial test for instrument research to 30 students. After 
that, the data of trial test of instrument is analyzed by validity and reliability test. When the research instrument is valid and reliable, then it can use to take data from the subject of the research.

Based on the trial test result of research intrument, it showed that the number of items valid for Locus of Control was 14 items, Student Perceptions of Teaching Methods was 18 items, and The Use of Learning Resources was 17 items. The reliability of research instrument was obtained that the value of Cronbach's Alpha of Locus of Control was 0.733, Student Perceptions of Teaching Methods was 0.862, and The Use of Learning Resources was 0.892 .

Data analysis technique used in this research were descriptive analysis, prerequisite analysis test, hypotheses test, and calculating the effective contribution and relative contribution.

In descriptive analysis, it used to analyze the data obtained from the respondents through questionnaires that have been filled by them then presented in the form of data description of each variable. Description of data includes mean, median, mode, frequency distribution table, variable trend table, and pie chart.

Prerequisite analysis test consist of Linearity test, Multicoliniearity Test. Hypothesis testing used in this research was simple regression and multiple regression. The simple regression is used for the first, second and third hypothesis, while the multiple linear regression is used for the fourth hypothesis.

\section{RESEARCH \\ RESULT \\ AND \\ DISCUSSION \\ Descriptive Analysis \\ Table 1. Mean, Median, Mode, Deviation Standard, \\ Maximum Score, Minimum Score of each variables:}

\begin{tabular}{|l|l|l|l|l|}
\hline Description & \multicolumn{1}{|c|}{ Y } & \multicolumn{1}{|c|}{ X1 } & \multicolumn{1}{c|}{ X2 } & \multicolumn{1}{|c|}{ X3 } \\
\hline Mean & 54.14 & 39.81 & 56.12 & 52.78 \\
\hline Median & 52 & 40 & 58 & 53 \\
\hline Mode & 46 & 45 & 53 & 43 \\
\hline $\begin{array}{l}\text { Deviation } \\
\text { Standard }\end{array}$ & 10.92 & 4.94 & 7.61 & 7.88 \\
\hline Maximum & 88 & 48 & 69 & 67 \\
\hline Minimum & 30 & 31 & 41 & 40 \\
\hline
\end{tabular}

Source: Primary Data Processed

\section{a). Accounting Learning Achievement}

Based on the table 1 , it obtained mean of 54.14 , median of 52 , mode of 46 , and deviation standard of 10.92 . The number of interval class using formula $\mathrm{K}=1+3,3 \mathrm{log}$ 81 was equal 7.29 rounded up to 8 . Class range was $88-30=58$, and interval class range obtained by $58 / 8=7.25$ rounded up to 8 .

\section{b). Locus of Control}

Based on the table 1, it obtained mean of 39.81 , median of 40 , mode of 45 , and deviation standard of 4.94 . The number of interval class using formula $\mathrm{K}=1+3,3 \mathrm{log}$ 81 was equal 7.29 rounded up to 8 . Class range was $48-31=17$, and interval class range obtained by $17 / 8=2.13$ rounded up to 3 .

c). Student Perceptions of Teaching Methods

Based on the table 1, it obtained mean of 56.12, median of 58, mode of 53, and deviation standard of 7.61. The number of interval class using formula $\mathrm{K}=1+3,3 \mathrm{log}$ 81 was equal 7.29 rounded up to 8 . Class range was $69-41=28$, and interval class 
range obtained by $28 / 8=3.5$ rounded up to 4.

\section{d). The Use of Learning Resources}

Based on the table 1, it obtained mean of 52.78 , median of 53 , mode of 43 , and deviation standard of 7.88. The number of interval class using formula $\mathrm{K}=1+3,3 \log$ 81 was equal 7.29 rounded up to 8 . Class range was $67-40=27$, and interval class range obtained by $27 / 8=3,38$ rounded up to 4 .

Research Hypothesis Test

Table 2. Result of Hypotesis Testing

\begin{tabular}{|c|c|c|c|}
\hline & $\mathbf{X 1}$ & $\mathbf{X 2}$ & $\mathbf{X 3}$ \\
\hline Coefficient & 1.794 & 0.871 & 0,988 \\
\hline Constanta & -17.287 & 5.243 & 2.011 \\
\hline $\mathrm{r}$ & 0.812 & 0.607 & 0,713 \\
\hline$r^{2}$ & 0.659 & 0.368 & 0,509 \\
\hline Sig & 0,000 & 0,000 & 0,000 \\
\hline
\end{tabular}

Source: Primary Data Processed

\section{a). First Hypothesis Test}

The results of this research shows that there is a positive influence of Locus of Control on Accounting Learning Achievement. Simple regression analysis obtained $r_{x 1 y}$ is 0.812 . The price of $r_{\text {table }}$ is 0.221 with $\mathrm{N}-77$ at $5 \%$ significance level. It means $r_{\text {value }}$ is higher than $r_{\text {table }}$ $(0.812>0.221)$. In addition the results of $\mathrm{r}^{2}{ }_{\mathrm{x} 1 \mathrm{y}}$ is 0.659 and $\mathrm{t}_{\text {value }} 12.351$ is and $\mathrm{t}_{\text {table }}$ 1.991 is with $5 \%$ significance level so it can be inferred that Locus of Control gives a positive influence on Accounting Learning Achivement. Thus, it can be said that the higher of Locus of Control, it will be followed by Accounting Learning Achievement.

The results from analysis are strengthened by the theory according to Rotter in Djiwandono (2002: 336) that Locus of Control is important to explain the students who get good learning achievement because students believe that succes and failure at school caused by Internal Locus of Control then because a fate or luck as well as other external factors called External Locus of Control. The statement by Abid, et al (2016) stated that academic achievement is depends on Locus of Control. Arslan and Akin (2014) also stated that Locus of Control is a key features of Academic Performance.

b). Second Hypothesis Test

The results of this research shows that there is a positive influence of Student Perceptions of Teaching Methods on Accounting Learning Achievement. Simple regression analysis obtained $r_{x 2 y}$ is 0.607 . The price of $r_{\text {table }}$ is 0.221 with $\mathrm{N}-77$ at $5 \%$ significance level. It means $r_{\text {value }}$ is hgher than $r_{\text {table }}$ $(0.607>0.221)$. In addition, the results of $\mathrm{r}^{2}{ }_{\mathrm{x} 2 \mathrm{y}}$ is 0.368 and $\mathrm{t}_{\text {value }} 6.786$ is and $\mathrm{t}_{\text {table }}$ 1.991 is with $5 \%$ significance level so it can be inferred that Student Perceptions of Teaching Methods gives a positive influence on Accounting Learning Achivement. Thus, it can be said that the better of Student Perceptions of Teaching Methods and quality of teaching methods, it will be followed by Accounting Learning Achievement.

The results from analysis above is supported by the theory according to Moskowitz and Orgel in Walgito (2010: 100) stated that perception is an integrated process within the individual against the stimulus it receives. Learning method means the how teacher deliver the material in the learning process so the students can obtained optimal results (Sugihartono, 2013: 81). Students can understand the methods applied by the teachers of the sensing process. The better methods applied by the teachers, the better perception about the teachers. Conversely, if the method used is not good, the students will have negative perceptions. A good or positive perception of the students about the teacher will make a good teaching environment and healthy relation with the teacher, so it will increases the 
capability of the students (Nasreen \& Naz, 2013: 30).

c). Third Hypothesis Test

The results of this research is a positive influence of The Use of Learning Resources on Accounting Learning Achievement. Simple regression analysis obtained $r_{x 3 y}$ is 0.713 . The price of $\mathrm{r}_{\text {table }}$ is 0.221 with $\mathrm{N}-77$ at $5 \%$ significance level. It means $r_{\text {value }}$ is higher than $r_{\text {table }}(0.713>0.221)$. In addition the results of $r^{2}{ }_{x 3 y}$ is 0.509 and $t_{\text {value }} 9.042$ is and $t_{\text {table }} 1.991$ is with $5 \%$ significance level so it can be inferred that The Use of Learning Resources gives a positive influence on Accounting Learning Achivement. Thus, it can be said that the more effective of The Use of Learning Resources, the better Accounting Learning Achievement.

The results from analysis above supported by Percival and Ellington in Sitepu (2014: 20) emphasizing that learning resources in education and training are deliberately created to enable learners to learn individually. Utilization of the available Learning Resources by students appropriately and effectively will certainly encourage students to achieve high Accounting Learning Achievement. Conversely, if students are less able to utilize the available learning resources, then the Accounting Learning Achievement will be low.

d). Fourth Hypothesis Test

Table 3. Fourth Hypothesis Test Result

\begin{tabular}{|c|c|c|c|}
\hline & $\mathbf{X 1}$ & $\mathbf{X 2}$ & $\mathbf{X 3}$ \\
\hline Coefficient & 1.249 & 0.239 & 0.384 \\
\hline Constanta & \multicolumn{3}{|c|}{-29.295} \\
\hline $\mathrm{R}$ & \multicolumn{3}{|c|}{0.870} \\
\hline$r^{2}$ & \multicolumn{3}{|c|}{0.748} \\
\hline Description & \multicolumn{2}{|c|}{ Positive and Significant } \\
\hline
\end{tabular}

The results of this research show a positive influence of Locus of Control, Student Perceptions of Teaching Methods, and The Use of Learning
Resources on Accounting Learning Achievement. Through multiple regression analysis obtained $r_{y(1,2,3)}$ is 0.870 . The price of $\mathrm{r}_{\text {table }}$ is 0.221 with $\mathrm{N}$ 77 at $5 \%$ significance level. It means $r_{\text {value }}$ is higher than $r_{\text {table }}(0.870>0.221)$. In addition the results of $\mathrm{r}_{\mathrm{y}(1,2,3)}$ is 0.758 and $F_{\text {value }} 80.242$ is and $F_{\text {table }} 2.723$ is with $5 \%$ significance level so it can be inferred that Locus of Control, Student Perceptions of Teaching Methods, and The Use of Learning Resources give a positive influence on Accounting Learning Achivement. The effective contribution of Locus of Control is $45 \%$, Student Perceptions of Teaching Methods is $12 \%$, and The Use of Learning Resources is $18 \%$ on Accounting Learning Achivement, while $25 \%$ comes from other variables of factors that are not examined in this research.

\section{Relative Contributions (SE) and Effective Contribution (SE)}

Table 4. Relative and Effective Contribution

\begin{tabular}{|l|c|c|}
\hline \multirow{2}{*}{\multicolumn{1}{|c|}{ Variable }} & \multicolumn{2}{c|}{ Contribution } \\
\cline { 2 - 3 } & Relative & Effective \\
\hline Locus of Control & $60 \%$ & $45 \%$ \\
\hline $\begin{array}{l}\text { Student } \\
\text { Perceptions of } \\
\text { Teaching } \\
\text { Methods }\end{array}$ & $16 \%$ & $12 \%$ \\
\hline $\begin{array}{l}\text { The Use of } \\
\text { Learning } \\
\text { Resources }\end{array}$ & $24 \%$ & $18 \%$ \\
\hline Total & $100 \%$ & $75 \%$ \\
\hline
\end{tabular}

Source: Primary Data Processed

Based on the table, it is showed that Locus of Control, Student Perceptions of Teaching Methods, and The Use of Learning Resources give $75 \%$ of effective contribution, while $25 \%$ from other variables that does not examine in this research. 


\section{CONCLUSION AND SUGGESTION Conclusions}

There is a positive influence of Locus of Control on Accounting Learning Achievement Students Class of X, XI, XII Accounting SMK Muhammadiyah 2 Moyudan Academic Year 2017/2018, with $\mathrm{r}_{\mathrm{x} 1 \mathrm{y}}=0.812, \mathrm{r}_{\mathrm{x} 1 \mathrm{y}}=0.659, \mathrm{t}_{\mathrm{value}}=12.351$, $\mathrm{t}_{\text {table }}=1.991$, by $5 \%$ significant level.

There is a positive influence of Student Perceptions of Teaching Methods on Accounting Learning Achievement Students Class of X, XI, XII Accounting SMK Muhammadiyah 2 Moyudan Academic Year 2017/2018, with $r_{x 2 y}=0.607, r_{x 2 y}^{2}=$ $0.368, \mathrm{t}_{\text {value }}=6.786, \mathrm{t}_{\text {table }}=1.991$, by $5 \%$ significant level.

There is a positive influence of The Use of Learning Resources on Accounting Learning Achievement Students Class of X, XI, XII Accounting SMK Muhammadiyah 2 Moyudan Academic Year 2017/2018, with $r_{x 3 y}=0.713, r_{x 3 y}^{2}=0.509, t_{\text {value }}=$ $9.042, \mathrm{t}_{\text {table }}=1.991$, by $5 \%$ significant level.

There is a positive influence of Locus of Control, Student Perceptions of Teaching Methods, and The Use of Learning Resources on Accounting Learning Achievement Students Class of X, XI, XII Accounting SMK Muhammadiyah 2 Moyudan Academic Year 2017/2018, with $\mathrm{r}_{\mathrm{y}(1,2,3)}=0.870, \mathrm{r}_{\mathrm{y}(1,2,3)}=0.758, \mathrm{~F}_{\text {value }}=$ $80.242, \mathrm{~F}_{\text {table }}=2.723$, by $5 \%$ significant level.

\section{Suggestions}

Based on the results of research and conclusion above it can be given suggestions as follows:

Students should ask the teacher or friends when find some difficulties in understanding the accounting material. Students better to give some opinions during the discussion to understand the material.

Teachers should give appreciations to the students when they are get good achievement and give motivation to the students who still get bad marks. Teacher also can give task in a group so student can discuss with their mates in the class. Teacher should give task when the teacher cannot attend the class.

In the next research, the researcher can find other factors that may influence the Accounting Learning Achievement by adding some variables which are not included in this research and by adding subjects of the research, not only in one school but also in many school in same region/organization.

\section{REFERENCES}

Abid, M.A., Kanwal, S., Nasir M. A.T., et al. (2016). The Effect of Locus of Control on Academic Performance of the Students at Tertiary Level. International Review of Management and Bussiness Research, 5(3), 860-869.

Ahmadi, A. \& Supriyono, W. (2004). Psikologi Belajar. Jakarta: PT Rineka Cipta.

Arikunto, S. (2006). Dasar-dasar Evaluasi Pendidikan. Jakarta: Bumi Aksara.

Arikunto, S. (2013). Manajemen Penelitian. Jakarta: Rineka Cipta.

Arslan, S. \& Akin, A. (2014). Metacognition: As a Predictor of One's Academic Locus of Control. Educational Sciences: Theory and Practice, 14(1), 33-39.

Darmawan, D. (2014). Inovasi Pendidikan. Jakarta: PT Remaja Rosdakarya Offset.

Djiwandono, S. E. (2002). Psikologi Pendidikan. Jakarta: Gramedia.

Ghufron, M. N. \& Risnawita, R. (2014). Teori-teori Psikologi. Yogyakarta: Ar Ruzz Media. 
Hasbullah. (2012). Dasar-dasar Ilmu Pendidikan. Jakarta: PT RajaGrafindo Persada.

Karwono \& Mularsih, H. (2017). Belajar dan Pembelajaran: Serta Pemanfaatan Sumber Belajar. Jakarta: PT RajaGrafindo Persada.

Nasreen, A. \& Naz, A. (2013). A Study of Factors Effecting Academic Achievement of Prospective Teachers. Journal of Social Science for Policy Implications, 1(1), 23-31.

Nodoushan, M. A. S. (2012). The Impact of Locus of Control on Language Achievement. International Journal of Language Studies, 6(2), 123-136.

Robbins, S. P. \& Judge, T. A. (2008). Perilaku Organisasi. (Terjemahan). Jakarta: Salemba Empat.

Sitepu. (2014). Pengembangan Sumber Belajar. Jakarta: PT RajaGrafindo Persada.

Slameto. (2013). Belajar dan Faktor-faktor yang Mempengaruhinya. Jakarta: Rineka Cipta.

Sudjana, N. (2005). Dasar-dasar Proses Belajar Mengajar. Bandung: Sinar Baru.

Sugihartono. (2013). Psikologi Pendidikan. Yogyakarta: UNY Press.

Sugiyono. (2014). Metode Penelitian Kuantitatif, Kualitatif, dan $R \& D$. Bandung: Alfabeta.

Walgito, B. (2010). Pengantar Psikologi Umum. Yogyakarta: CV Andi Offset. 